\title{
Does Anatomical Structure of Stem Cuttings Affect Root Formation?
}

Mohamed M. Gad and Fatma Al-Zahra K. K. Attia

Ornamental Plants Dept., Fac. Agric., Assiut University

Mohamed.mohamd1@agr.au.edu.eg

Fatma.kamel@agr.au.edu.eg

Received on: 5/6/2017

Accepted for publication on: $6 / 6 / 2017$

\begin{abstract}
There was an apparent difference in tissue origin of adventitious roots in stem cuttings collected from Dracaena and Cordyline. Dracaena was difficulty rooting but Cordyline root quickly and easily when cuttings are taken from stock plants. The reasons for this could be due to their anatomy. The difficult-to-root cutting in Dracaena related to the presence of sclerenchyma ring between phloem and cortex. So Dracaena cutting require the application of auxin that has effects on the anatomical events that associated with the rooting process. The ease-toroot cutting Cordyline occurs as a result of the presence of preformed initials form within the cutting tissues that occurs readily on cutting without the need for special treatments of root formation. Hence, it is necessary to use anatomical study as indicator/markers of rooting ability.

The application of IBA at $1000 \mathrm{ppm}$ proved to be the most effective treatment in stimulating adventitious root formation on Dracaena cutting; it recorded $72.7 \%$ rooting followed by IAA $(45.7 \%)$, NAA $(32.3 \%)$ and untreated one $(22.2 \%)$. However, these promoting substances resulting in approximate higher rooting percentages in Cordyline cuttings; IBA (100\%), NAA (97.4\%), IAA $(96.9 \%)$ and control $(92.7 \%)$ than in Dracaena ones.

Apparently, it is important to study the anatomical structure of stem cuttings for commercial production and what growth substances suitable for each to overcome the difficult-to-root problem.
\end{abstract}

Keywords: Stem anatomy, Cutting structure, Growth regulators, Dracaena, Cordyline.

\section{Introduction}

Dracaena marginata, Lam. (family Agavaceae) and Cordylineterminalis, L. (family Liliaceae) are favored as interior ornamental plants. They are famous for having a special kind of attraction for their beautiful shapes with bright linear leaves that established themselves among the foliage plants are considered very important for commercial production.

A little information is available about the reasons of difficult or easeto-root cuttings in indoor plants. So the aim of this study was to summa- rize current knowledge associated with the anatomical aspects of adventitious root formation. A good example has been used as a difficult-toroot (Dracaena marginata, Lam.) and another easily-to-root (Cordyline terminalis, L.). Moreover, exogenous auxin treatments such as IAA, IBA and NAA cause considerable influences concerning overcome the difficult- to-root cuttings by stimulating the initiation of adventitious roots and inducing high rooting capacity; Hartman et al (2002).

Relationship between anatomical structure of stem and rooting ca- 
pacity had been studied in a wide range of plants. The location of origin where adventitious roots originate inside the stem has been discussed by plant anatomists. El-Nashar (2008) stated that treating Jasminumsambac and Pittosporum tobira cuttings with IBA at 100 or $200 \mathrm{ppm}$ stimulated the initiation of roots and affected the sclerenchymatous tissue making it loose, thus the root initial can easily emerge. Fouda et al. (2012) noticed that narrow phloem tissue, cambial zone and vascular rays beside badly and slowly formation of the vascular connection between the new roots and the vascular tissues of the cuttings seemed to be mostly responsible for difficult-to-root cuttings of lemon verbena. Alavi et al. (2015) reported that IBA had an essential role in stimulation of cell division in pericycle, reflecting on more rooting on Rosmarinus officinalis cuttings. Lodama et al. (2016) revealed that treating cuttings of Lobostemonfruticosus with IBA auxin stimulated the root initiation. They stated that the callus tissue started to develop from the vascular cambium close to the cut end of the cutting. Parenchyma gaps in the phloem fiber ring close to the cut end of the cuttings was also observed.

\section{Materials and Methods}

The experiment was carried out at the Floriculture Farm, Faculty of Agriculture, Assiut University for two successive seasons (2012/13 and 2013/14) to investigate if the anatomical structure of stem affect root formation in Dracaena marginata, Lam. as a difficult-to-root plantand Cordyline terminalis, L. as an easyto-root cutting. Moreover, if the syn- thetic hormones can ease and stimulate rooting ability.

On mid-March of 2012 and 2013 seasons, leafless cuttings of 5-7 $\mathrm{cm}$ long were taken from intermediary woody portion of the branches from one-year-old shoots of healthy mature mother plants. All tested cutting bases were humidified with hot water $\left(45{ }^{\circ} \mathrm{C}\right.$ for $5 \mathrm{sec}$.) then thoroughly dipped for $10 \mathrm{sec}$. in the mixture of talc powder + fungicide "Rizolex $^{\mathrm{TM}}$ " as a basic treatment (control). The growth regulator of IAA, IBA or NAA was mixed individually with the basic mixture to reach a concentration of $1000 \mathrm{ppm}$.

The experiment was placed under saran house conditions $(70 \%$ shade) and ambient temperatures of $20-35^{\circ} \mathrm{C}$ treatments of each species were separately arranged in a complete randomized blocks design. Each treatment (8 cuttings/ pot) replicated four times. Cuttings of both species were planted in $20 \mathrm{~cm}$-diameter plastic pots filled with peat moss + perlite $(1: 2 \mathrm{v} / \mathrm{v})$ and covered by tightly polyethylene film to maintain high relative humidity (75-80\%).

Twenty-five weeks after planting for Dracaena and 6 weeks for Cordyline, different cutting treatments were dug up, cleaned, and the data were recorded on percentage of rooted cuttings (which produced visible roots). Data were statistically analyzed using Statistix 8.1 analytical software and the means were compared using a least significant difference (L.S.D) test according to Dowdy and Wearden (1983).

Anatomical structure of stem segments of Dracaena and Cordyline during rooting was investigated to:(1) 
determine if low rooting capacity is related to anatomical features, (2) establish whether preformed root primordia are present or a site for primordium formation must be createdand (3) identify the cell tissues from which the roots originate.

Stem segments of $1.5 \mathrm{~cm}$ long of cutting bases (in rooting zone) were fixed in formalin: alcohol: glacial acetic acid (1:18:1 by volume) using $70 \%(\mathrm{v} / \mathrm{v})$ ethanol in water in the fixative and for storage after a minimum fixation of three days according to Amissah et al. (2008). Samples of cuttings were taken after 30, 60 and 90 days for Dracaena and after 10,20, 30 and 40 days from propagation for Cordyline. Cuttings washed then transverse sections cut by sliding microtome with 6-9 micronthickness. The double stain of safranin-light green was used by clearing in xylol mounted in DPX according to El-Nashar (2008). Transverse sections were photographed using a five-megapixel camera attached to an optical microscope under the control of a computer. Selections of transverse sections were based on section quality and clarity of the recorded images. At the magnification used (400x), the anatomical structures were photomicrographed.

\section{Results and Discussion} Rooting percentage:

It is clearly noticed that the rooting ability of the untreated cut- tings of Dracaena was very poor (22.2\% average of two seasons), since it was greatly influenced by the different root-promoting substances (Table 1 and Fig.1). The high degree of response to rooting was obtained by IBA treatment ( $72.7 \%$ in average) with significant increases compared to IAAtreated cuttings $(45.7 \%)$, NAA treatment $(32.3 \%)$ and control. These results are in agreement with those reported on Dracaena spp.; Hata et al. (1994), Anit and Arquiza (1999), Bargamento (1999) and Pushpamali et al. (2004). They concluded that IBA is superior among growth regulators in stimulating the adventitious root formation in Dracaena cuttings showing higher rooting percentage than other treatments. On contrary, untreated cuttings of Cordyline showed adverse trend as recorded 87.5 and $97.9 \%$ rooting in the first and second seasons, respectively. Applications of IAA, IBA and NAA treatments significantly increased rooting percentage compared to control in the first season. Although the growth regulators showed, mostly, insignificant effect among them, IBA was the most effective treatment resulted in the maximum percentage of rooting $(100 \%)$ during both seasons. These results are in conformity with those reported by Rahdari et al. (2014) on Cordyline terminalis.

Table 1. Percentage of rooted cuttings in Dracaena marginata, Lam. and Cordyline terminalis, $\mathrm{L}$ as affected by growth regulators during 2012 and 2013 seasons.

\begin{tabular}{|l|c|c|c|c|}
\hline \multirow{2}{*}{ Growth Regulators } & \multicolumn{2}{|c|}{ Dracaena marginata } & \multicolumn{2}{c|}{ Cordyline terminalis } \\
\cline { 2 - 5 } & $\mathbf{2 0 1 2} / \mathbf{2 0 1 3}$ & $\mathbf{2 0 1 3} / \mathbf{2 0 1 4}$ & $\mathbf{2 0 1 2} / \mathbf{2 0 1 3}$ & $\mathbf{2 0 1 3 / 2 0 1 4}$ \\
\hline Control & 22.67 & 21.67 & 87.50 & 97.92 \\
\hline IAA & 55.50 & 35.83 & 100.00 & 93.75 \\
\hline IBA & 72.83 & 72.50 & 100.00 & 100.00 \\
\hline NAA & 33.00 & 31.67 & 96.88 & 97.92 \\
\hline LSD $_{\mathbf{0 . 0 5}}$ & $\mathbf{7 . 5 5}$ & $\mathbf{8 . 3 2}$ & $\mathbf{4 . 9 9}$ & $\mathbf{5 . 5 5}$ \\
\hline
\end{tabular}


The effects of auxins on rooting and plant development have been discussed in several studies. Hartmann et al. (2002) stated that auxin plays a vital role in stimulating the adventitious root formation on cuttings. Root initials in cuttings are dependent upon the native auxins in the plant plus an auxin synergist together, these lead to synthesis of ribonucleic acid which involved in initiation of the root primordia. Other authors reported that auxins control growth and development in plants, including lateral root initiation and root gravity response. The exogenous application of auxins increased initiation of lateral roots and that lateral root development is highly dependent upon auxin group and auxin transport. The degree of auxin activity depends on its structural peculiarities and configuration; Chhun et al. (2003) and Štefanèiè et al. (2005)

The processes of adventitious root formation at the base of a cutting may be divided into three stages: initiation, elongation of root initials, and root growth and development; Hartmann et al. (2002). Three growth regulators (IAA, IBA and NAA) may be applied to regulate and/or influence the rooting process in some way: (a) hormones, which induce the initial meristematic activity; Davis and Haissig (1990) and stimulate the elongation and development of roots formed; Hartmann et al. (2002), and(b) nutritional elements promote growth of the new roots and protecting agents such as biocides which enable the cuttings to resist attack by pathogens during the entire rooting period; Wiesman and Lavee (1995).

\section{Anatomy of adventitious root for- mation}

In comparison, anatomical structure of the stem cutting of Dracaena (Fig.2A) proved the presence of some difficulties-to-root. During the root primordium formation phase, the first well-developed young root meristems became visible, it is found an obstacle in the form of a sheath of sclerenchyma between the phloem and cortex which defects the root from its normally radial course. On contrast, the ease-to-root cutting section of Cordyline contains "preformed primordia" (Fig.2B). As these are initiated when plants are intact; the early stages at least should not be complicated by wound responses. The rate of development of "preformed primordia" is greatly accelerated in cutting.

On the bases of anatomical studies, the processes of root formation at the base of stem cutting are divided into three stages; (a) the root initiation, (b) the root primordium formation and (c) root growth and development (root elongation and emergence); Hartmann et al (2002). These anatomical events were studied precisely on cutting bases of Dracaena marginata response to the application of some growth regulators and cuttings taken from different portions for 90 days after planting; JuraMorawiec (2015).

The important features in the difficult-to-root cuttings which are likely to inhibit the natural capacity to initiate and develop root primordia are the continuous sclerenchyma ring between the phloem and cortex may constitute an anatomical barrier to emergence of adventitious roots. 
Dracaena marginata, Lam.:

Transverse sections of the rooting zone of cutting of Dracaena revealed that no detectable anatomical changes were observed at the cutting base beginning of the first 30 days after IBA application, (Fig.3A) somewhat callus development in the rooting bench was noticed in cortex. In general, the rate of tissue swelling of callus on the bases of IBA-treated cuttings became noticeable on the $30^{\text {th }}$ day and subsequently grew rapidly in size. Microscopic studies showed that meristematic activity accompanied with this swelling. These newly formed cells proliferated mainly from vascular cambium and in part from phloem and xylem parenchyma, the continuous sclerenchyma ring between the phloem and cortex is presence. After 30 days from propagation, the induction and activation which involves cell division are observed. In the case of primordia occurring in situ division of the phloem, parenchyma, cambium or recent derivatives of the cambium were taken place. The meristematic cells of initial root continuously divide forming elongation allowing it to penetrate through phloem and sclerenchyma ring. For rooting active proliferation of parenchyma ray cells resulting in rupturing of the continuity of the sclerenchymatic tissue leaving small gaps in the sclerenchyma sheath, where root primordial grew down inside the fiber sheath and emerged through the gaps to the base of the cutting.

After 60 days from propagation, proliferations in the secondary phloem eventually superseded in extent those in the cortex (Fig.3B). The extensive proliferation in the phloem was coincident with the eventual location of root primordium, root initial had formed within the proliferative tissue at this location, in the secondary phloem at some distance from cambium. The root primordium had developed acquiring a dome-shaped apex with a differentiated root cap and subsequently vascular differentiation.

After 90 days from propagation, differentiation of root primordium led to the formation of somewhat spirally oriented protuberance, this finger-like protuberance at first had no connection with the main vascular system, but still gave a rise to root initial continuous cell division, differentiation and subsequent distal elongation of this initial gave rise to root primordium having complete vascular connection with the main stem (Fig.3C). Fully developed root primordium grew and emerged outward crashed the cells adjacent to the root cap and forced its way between fiber strands, displacing them laterally. The emerged root had reached the outer cortex, attended by progressive differentiation of their vascular system. The new root had emerged through the ruptured sclerenchyma ring to pass through split in the epidermis in successful cutting.

By the time of root emergence fully matured vascular connections had been established between the vascular system of the adventitious roots and that of the cutting. Similar observations were noted by Mahros et al. (1994) on Melalaucaarmillaris, El-Sallami and Mahros (2000) on poinsettia, and El-Nashar (2008) on Jasminumsambac. They found in their studies that the poor rooting of 
difficult-to-root cuttings was related to the presence of sclerenchyma ring which acted as mechanical barriers preventing the emergence of roots. Studies of woody species that are difficult-to-root suggest that poor adventitious rooting ability may be associated with the presence of a ring of sclerenchymatous tissue. Other earlier studies declared the favourable effects of IBA on cell division, cell elongation and certain stages of differentiation during adventitious rooting; Abdel-Kader et al. (2004) on Ficusretusa, El-Nashar (2008) on Jasminumsambac and Alavi et al. (2015) on Rosmarinus officinalis. Less stimulated effective of IAA than IBA on rooting was attributed to a few root primordial actually formed in the cutting and the sclerenchymatic sheath without rupturing and less activities of cambial cells. In the meantime, NAA is seen as inhibitor of adventitious root formation, even when some positive effects have been observed.

Several other physiological effects of IBA treatment have been reported by some authors. AgullóAntón et al. (2011) demonstrated that the stimulation of adventitious root formation in cuttings by exogenous IBA, when applied to the rooting zone, increased sugar availability at the site of root primordial development, activates the sugar metabolism that releases energy and provides carbon skeletons for the synthesis of other essential compounds such as proteins. Pop et al. (2011) discovered that exogenous IBA applied to the rooting zone increased the rate of ethylene biosynthesis and stimulates an auxin-ethylene relation during root development has been observed.

Nag et al. (2001) assumed that rooting-phases have different auxin requirements. There is always a temporary increase in the endogenous level of free IAA during the inductive phase (corresponding to a minimal level of peroxidase activity). The inductive phase (initiation phase) characterized by a decrease in IAA levels to a minimum and high peroxidase and oxidase activity. Štefanèiè et al. (2007) emphasized that the IAA oxidation at this stage of rooting (initiation phase) seems to be related to IBA response. Oxidation products of IAA may promote root formation, especially when linked to the phenolic compounds present. During the root expressive phase, IAA is again needed to promote the growth of root's initials.

Cordyline terminalis, L.: Transverse sections of the rooting zone of IBA-treated cutting of Cordyline after 10 days from propagation show the induction and activation which involves cell divisions. In the case of pre-formed root primodia are present occurring in situ division of the phloem parenchyma, cambium or recent derivatives of the cambium usually takes place (Fig.4A).

After 20 days from propagation, divisions of the cells at the original location of the primordial initials were done. However, the initiation of meristematic activity of developing root meristem and the first differentiating root prmordium with an organized meristem appear. Increase in cell number and beginning of organization. When the structure becomes organized, beginning at the root tip. 
Root primordium close to emergence showing a tendency to form domelike structure (Fig.4B).

After 30 days from propagation, further increases in complexity and development into a root; root cap is present, also root elongation and complete differentiation of the root vascular system of the root by time of root emergence (Fig.4C).

After 40 days from propagation, emerging a fully developed adventitious root outward showing complete differentiation of cells of the root body containing the vascular system, which continuous with that of the stem. Root had reached the outer cortex and emerged through a split in the epidermis in successful cutting. It reveals morphological characteristics of the complete roots (Fig.4D).

Although the addition of auxins is not always essential for induction of rooting on cutting, the application of auxin reduces the time required to obtain the maximum percentage of rooting. Hunt et al. (2011) reported that the application of exogenous auxin is required to achieve rooting and auxin may be more beneficial for increasing rooting in difficult-to-root rather than in easy-to-root cuttings. Application of auxin, particularly IBA, is one of the most effective in enhancing the rooting. Cutting often responds optimally to auxin application during the differentiation phase of adventitious root formation. Completed adventitious rooting results in functional roots with the usual anatomical characteristics. However, specific anatomical changes during rooting may differ markedly between species and often between tissues of the same species.

\section{Literature Cited}

Abdel-Kader, H.H.; R. A. Fouda; M.N. Sharaf El-Din and F.G. ElSherbieny (2004): Effects of hydrogel and different application techniques of indole-3-butyric acid on the stem cuttings of some ficus trees. J. Agric. Sci. Mansoura Univ., 29 (7): 4125 - 4147.

Alavi, N.F.; Z. Asrar and H. Mozafari (2015): The effect of vitamin B1 and IBA on rooting and cortex cells growth of adventitious root in Rosmarinus officinalis L. cuttings under hydroponic media. Iranian J. Med. Aromatic Plants, 31 (1): 1630.

Amissah, J.N.; D.J. Paolillo Jr. and N. Bassuk (2008): Adventitious root formation in stem cuttings of Quercus bicolor and Quercusmacrocarpa and its relationship to stem anatomy. J. Amer. Soc. Hort. Sci., 133 (4): 479-486.

Anit, J.A. and A.L. Arquiza (1999): Propagation of Dracaena surcolosa "Florida Beauty". Philippine J. Crop Sci., 24 (1): 77. [Abstract Available from: http://agris.fao.org/agrissearch/sear chdo?recordID=PH1999101376].

Agulló-Antón, M.Á.; J. Sánchez-Bravo; M. Acosta and U. Druege (2011): Auxins or sugars: what makes the difference in the adventitious rooting of stored carnation cuttings? J. Plant Growth Regul., 30 (1): 100113.

Bargamento, L.M.M. (1999): Rooting response of Dracaena marginata (Agavaceae) 'Ivory' stem cuttings to various rooting preparations. Annual Scientific Conference of the Federation of Crop Science Societies of the Philippines, Gen. Santos City, South Cotabato, Philippines, 24:7. [Abstract available from: 
http://agris.fao.org/agrissearch/sear ch.do?record ID=PH1999101377].

Chhun, T.; S. Taketa; S. Tsurumi and M. Ichii (2003): The effects of auxin on lateral root initiation and root gravitropism in a lateral rootless mutant Lrt1 of rice (Oryza sativa L.). Plant Growth Regul., 39 (2): 161-170.

Dowdy, S. and S. Wearden (1983): Statistics for Research. John Wiley and Sons, New York, USA, pp. 640.

Davis, T.D. and B.E. Haissig (1990): Chemical control of adventitious root formation in cuttings. Bull. Plant Growth Regul. Soc. Amer., 18: 1-17.

El-Nashar, M.F. (2008): Application of auxins, vitamins and bacteria to hard to root cuttings for commercial production of two ornamental shrubs. Ph.D. Thesis, Fac. Agric., Assiut Univ., Egypt.

El-Sallami, I.H. and O.M. Mahros (2000): Effect of some growth regulators and branch portion on rootability of cutting, vegetation and flowering of poinsettia. Assiut J. Agric. Sci., 31 (5): 71-94.

Fouda, R.A.; H.H. Abdel-Kader; K.H. El-Hindi; H.Y. Massoud and F.R. Ibrahim (2012): Effect of wounding, auxin type and concentration on rooting of lemon verbena (Aloysiatriphylla (l'her.) Britton) plant. J. Plant Production, Mansoura Univ., 3 (12): 2927-2943.

Hartmann, H.T.; D.E. Kester; F.T. Davies and R.L. Geneve (2002): Plant Propagation: Principles and Practices. $7^{\text {th }}$ Edition, Upper Saddle River, New Jersey, pp. 341-410.

Hata, T.Y.; A.H. Hara; M.A. Nagao and B.K.S. Hu (1994): Hot-water treatment and indole-3-butyric acid stimulates rooting and shoot development of tropical ornamental cuttings. HortTechnology, 4 (2): 159-162.

Hunt, M.A.; S.J. Trueman and A. Rasmussen (2011): Indole-3-butyric acid accelerates adventitious root formation and impedes shoot growth of Pinuselliottiivar. elliottii $\times$ P. caribaea var. hondurensis cuttings. New Forests, 41 (3): 349360.

Jura-Morawiec, J. (2015): Formation of amphivasal vascular bundles in Dracaena draco stem in relation to rate of cambial activity. Trees, 29:1493-1499.

Lodama, K.E.; E.S. du Toit; J.M. Steyn; H.T. Araya; G. Prinsloo; C.P. du Plooy and P.J. Robbertse (2016): Improving rooting of Lobostemonfruticosus L. cuttings with delayed auxin treatment. South African J. Botany, 105 (7): 111-115.

Mahros, O.M.; G.T. Mousa; N.M. Abdalla and N.E. El- Keltawi (1994): Effect of time, growth regulators and branch portions on rooting of cuttings of some woody ornamental plants. Proc. $1^{\text {st }}$ Conf. Orna. Hort., p. 280:292, Fac. Agric., Cairo Univ., Cairo, Egypt.

Nag, S.; K. Saha and M.A. Choudhuri (2001): Role of auxin and polyamines in adventitious root formation in relation to changes in compounds involved in rooting. J. Plant Growth Regul., 20: 182-194.

Pushpamali, I., M.P. Hettiarachchp and L. Dissanayake (2004): Rooting of Dracaena sanderianacuttings as influenced by chemical sterilization and IBA application. Proceedings of the Second Academic Sessions, p. 196-199, Fac. Agric., Ruhuna Univ., Kamburupitiya, Sri Lanka.

Pop, T.I.; D. Pamfil and C. Bellini (2011): Auxin control in the formation of adventitious roots. Not. 
Bot. Hort. Agrobot. Cluj., 39: 307316.

Rahdari, P.; M. Khosroabadi, K. Delfani and S.M. Hoseini (2014): Effect of different concentration of plant hormones (IBA and NAA) on rooting and growth factors in root and stem cuttings of Cordyline terminalis. J. med. Bioengineering, 3 (3): 190-194.

Štefančič, M.; F. Štampar and G. Osterc (2005): Influence of IAA and IBA on root development and quality of
Prunus "GiSelA5" leafy cuttings. HortScience, 40 (7): 2052-2055.

Štefančič, M.; F. Štampar; R. Veberič, and G. Osterc (2007): The levels of IAA, IAAsp and some phenolics in cherry rootstock "GiSelA5" leafy cuttings pretreated with IAA and IBA. Scientia Hort., 112 (4): 399-405.

Wiesman, Z. and S. Lavee (1995): Enhancement of IBA stimulatory effect on rooting of olive cultivar stem cuttings. Scientia Hort., 62 (3), 189-198. 


\section{هل يؤُثر التركيب التشريحى للعقل الساقيه على تكوين الجذور؟ محمد مصطفى جاد و فاطمة كمال كامل \\ قسم الزينة - كلية الزر اعة - جامعة اسيوط}

أجريت الدراسة بمزرعة أبحاث نباتات الزينة - كلية الزر اعة - جامعة أسـيوط خــال

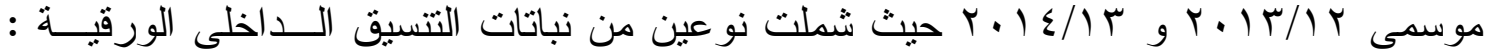

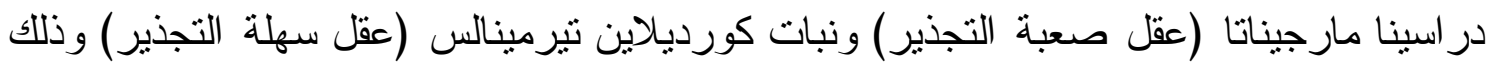

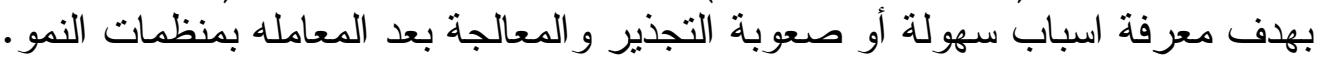

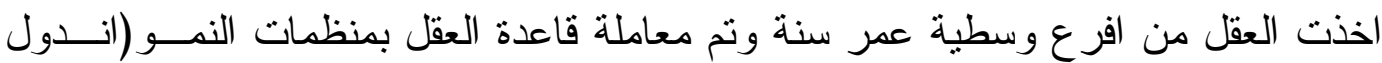

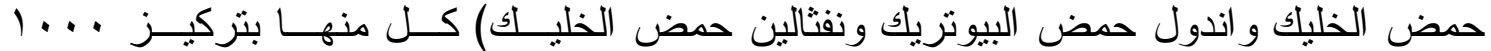

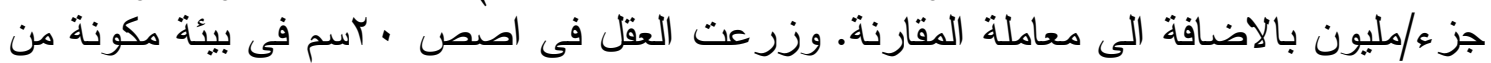
البيتموس و البرليت (البئنة (ابالحجم).

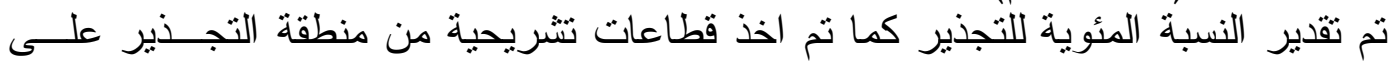

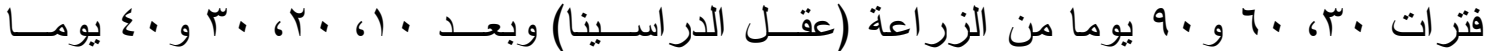

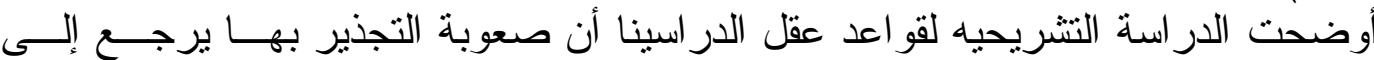

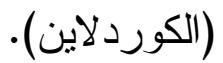

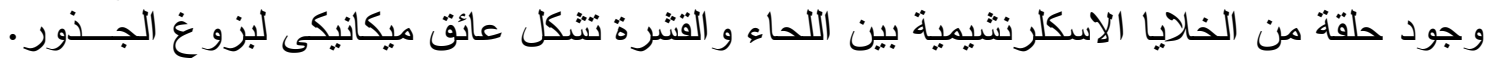

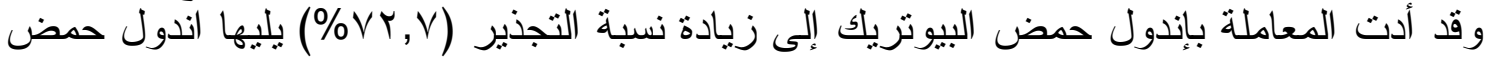

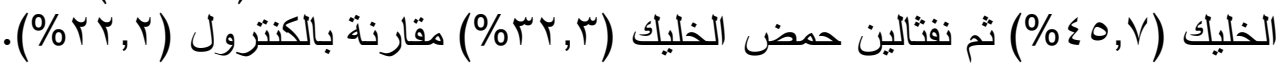

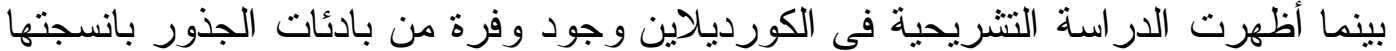

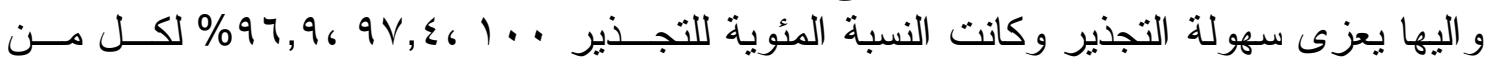

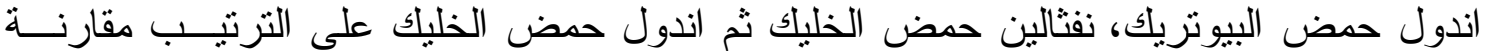

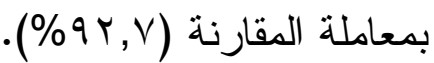

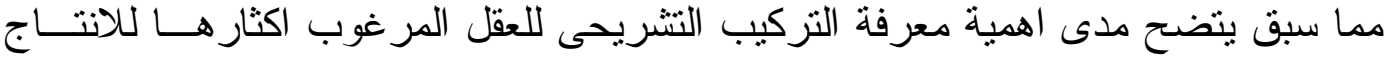

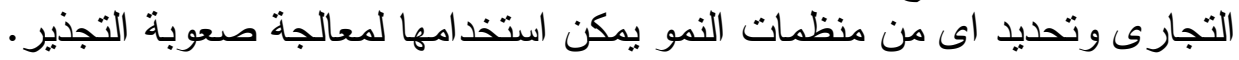




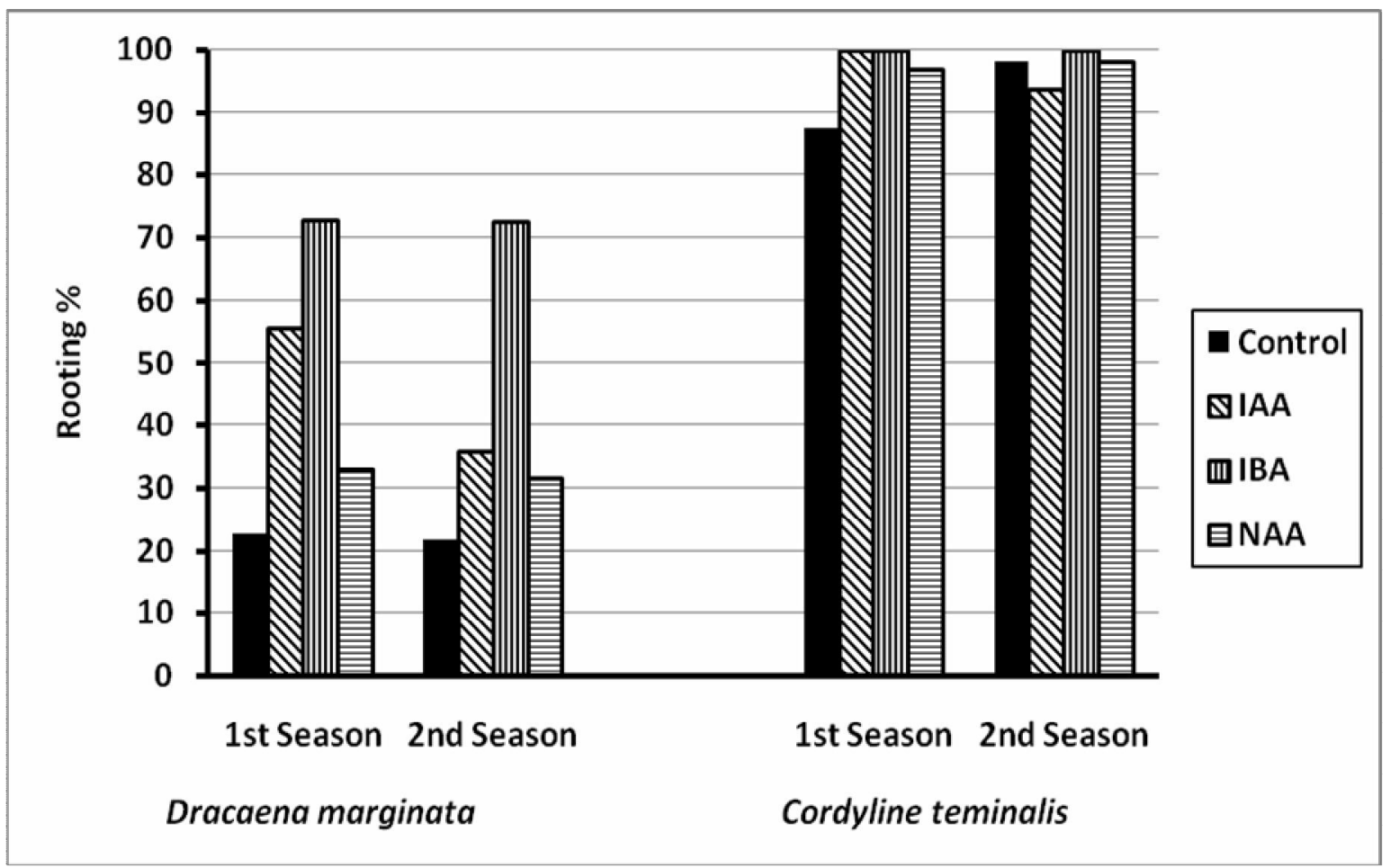

Fig. 1. Percentage of rooted cuttings in Dracaena marginata, Lam. and Cordyline terminalis, L as affected by growth regulators during 2012 and 2013 seasons

A

B

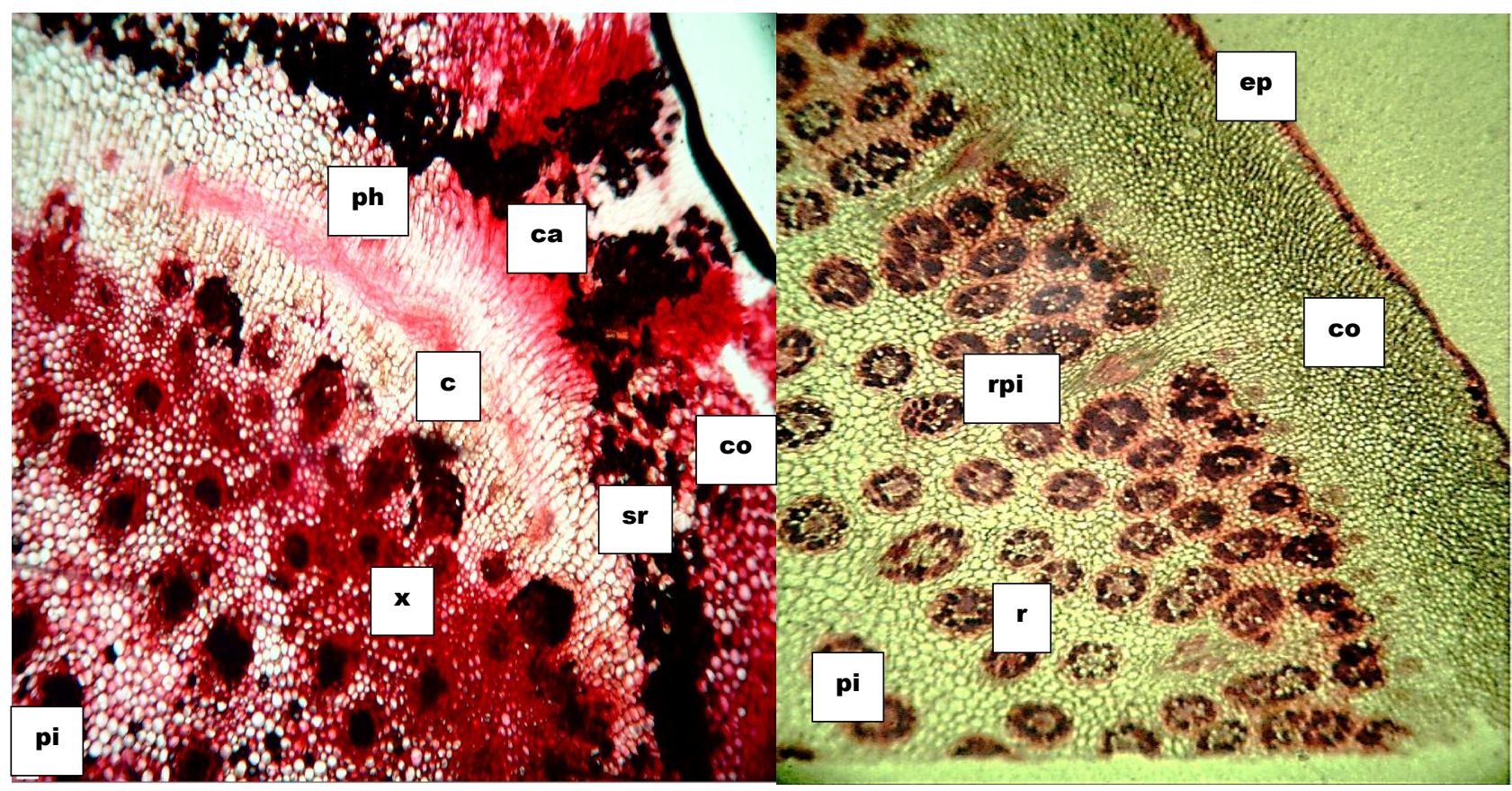

Fig.2: Transverse sections in the rooting zone of Dracaena marginata (A) after 30 days from propagation. (B) Cordyline terminalis after 10 days from propagation (400x). Callus (ca)- cortex (co)-sclerenchyma ring (sr)- Secondary phloem (ph)secondary xylem (x)- vascular cambium (c)- pith (pi)- root primordium initials (rpi)- epidermis (ep)- ring of vessels. 
A

B

C

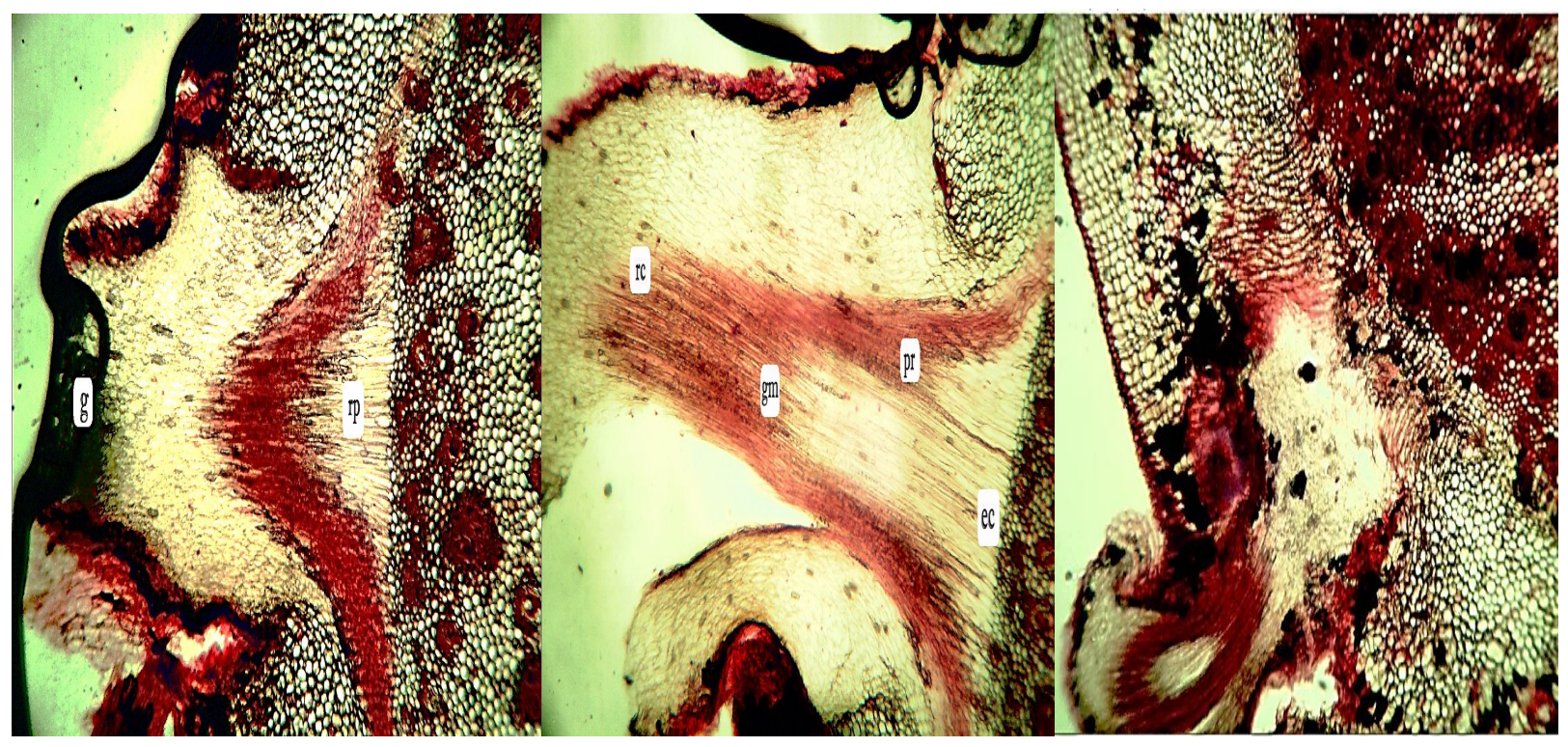

Fig.3: Transverse sections in the rooting zone of Dracaena marginata cutting response to the application of 1000 ppm IBA after 30 days (a), 60 days (B) and 90 days (C) from propagation. $400 \mathrm{x}$.

Root primordium (rp)- parenchymatous gap (g)- procambium (pr), ground meristem (gm) and root cap (rc)- elongated cells (ec) 
A

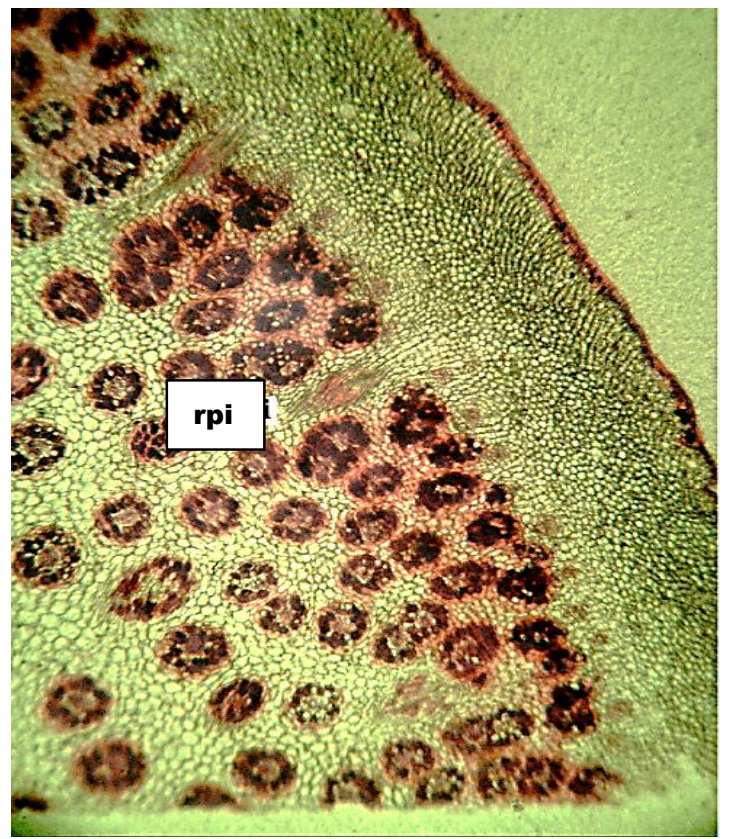

B

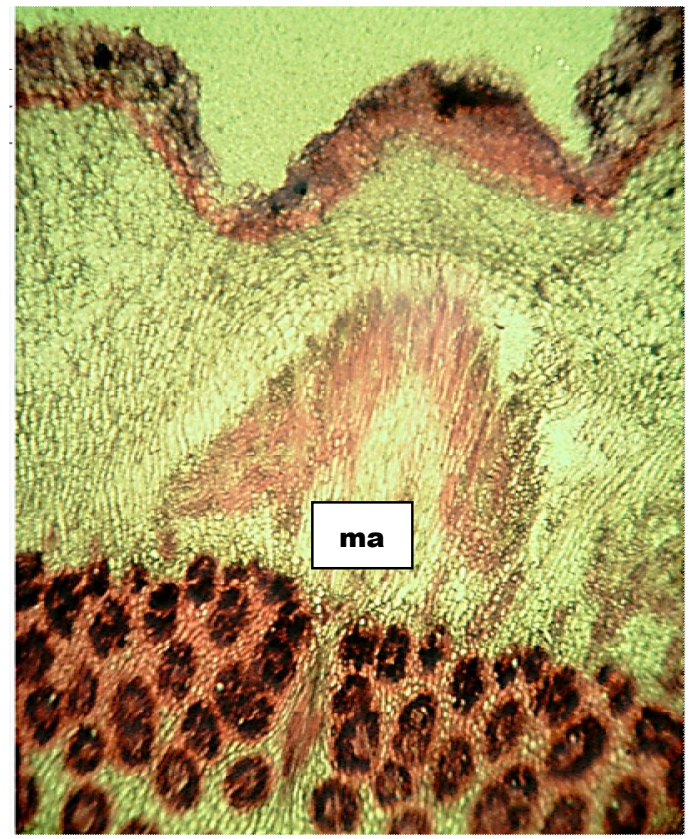

C

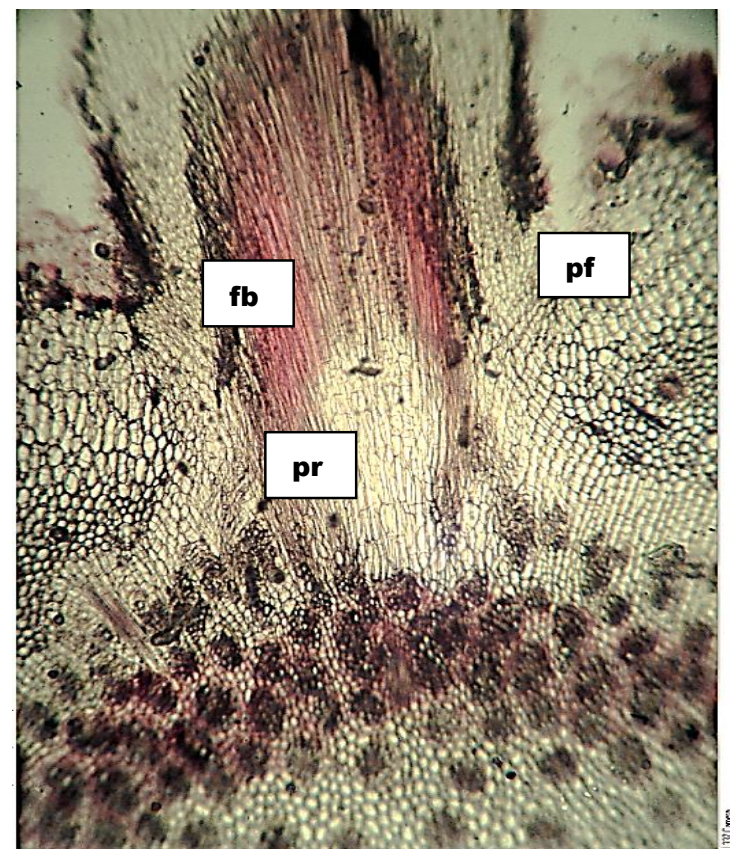

D

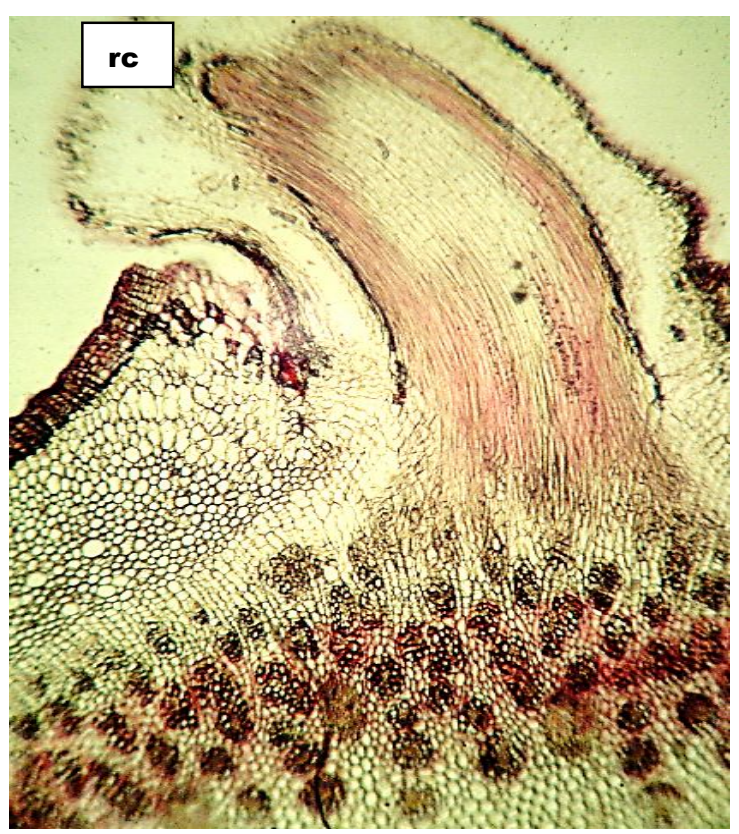

Fig. 4:Transverse sections of the rooting zone of Cordyline terminalis cutting response to the application of $1000 \mathrm{ppm}$ IBA after 10 (A), 20 (B), 30 (C) and 40 (D) days from propagation. 400x.

Root cap (rc)- phloem fibers (pf)- procambium (pr)-fiber bundles (fb)- root primodium initials (rpi) - meristematic activity (ma). 